\title{
Uji Aktivitas Hair Tonic Madu Kombinasi Ekstrak Daun Seledri (Apium Graveolens Linn) Terhadap Pertumbuhan Rambut Kelinci Jantan
}

\author{
Dzun Haryadi Ittiqo ${ }^{\mathrm{a},{ }^{*}}$,Putri Jeniti ${ }^{\mathrm{a},{ }^{2}}$,Melati Permata Hati ${ }^{\mathrm{a}, 3}$,Baiq Nurbaety ${ }^{\mathrm{a}, 4}$,Abdul Rahman \\ Wahid ${ }^{\mathrm{a}, 5}$ \\ a Program studi farmasi FIK Universitas Muhammadiyah Mataram, Mataram, Indonesia \\ 1 dzun.haryadi@gmail.com* \\ * korespondensi penulis
}

INFO ARTIKEL ABSTRAK

Diterima :

27-0I-2022

Direvisi :

28-0I-2022

Disetujui :

30-0I-2022

Seledri adalah tanaman yang memiliki efek terhadap pertumbuhan rambut, selain seledri madu telah banyak diketahui sebagai bahan alami yang berguna untuk merawat dan menyehatkan kulit kepala serta rambut karena kandungan madu sendiri kaya akan antioksidan yang penting bagi kesehatan rambut. Penelitian ini bertujuan untuk mengetahui aktivitas hair tonic madu kombinasi ektrak seledri terhadap pertumbuhan rambut kelinci serta uji mutu fisik hair tonic. Desain penelitian ini adalah eksperimental menggunakan hewan uji kelinci jantan jenis

\section{Kata kunci:}

Hair Tonic;

Seledri;

Madu;

Pertumbuhan Rambut. New Zealand dengan variasi konsentrasi dosis seledri dan madu untuk Formula A ( $5 \%$ : 15\%), Formula B (10\% : I0\%), Formula C (15\% : I5\%), kontrol normal (tanpa perlakuan), kontrol negatif (bahan tambahan), dan kontrol positif (sediaan hair tonic mengandung minoxidil 2\%). Uji mutu fisik meliputi organoleptis dan uji $\mathrm{pH}$. Pengukuran pertumbuhan rambut dilakukan pengamatan selama I4 hari. Data hasil pengukuran panjang dan berat rambut diuji statistik dengan metode uji Anova . Hasil penelitian menunjukan bahwa sediaan hair tonic kombinasi ekstrak daun seledri dan madu memenuhi syarat PH dan menghasilkan warna, bau, dan kejernian yang stabil selama penyimpanan. Kombinasi ekstrak daun seledri dan madu yang memiliki potensi paling tinggi terhadap pertumbuhan rambut kelinci adalah formula B, dengan perbandingan konsentrasi ekstrak $10 \%$ dan madu $10 \%$ dan tidak ada perbedaan yang signifikan $(\mathrm{p}<0,05)$ dengan kelompok positif . Kesimpulan pada penelitian ini adalah Hair tonic kombinasi ekstrak daun seledri dan madu memenuhi kriteria syarat Mutu Fisik dan Formula B memiliki potensi paling tinggi dan sama besar dengan kontrol positif terhadap aktivitas pertumbuhan rambut kelinci.

Key word:
Hair Tonic;
Celery;
Honey;
Hair growth activity.

\section{ABSTRACT}

Celery is a plant that has an effect on hair growth, in addition to celery honey has been widely known as a natural ingredient that is useful for treating and nourishing the scalp and hair because the content of honey itself is rich in antioxidants that are important for hair health. This study aims to determine the hair tonic activity of honey celery extract combination on rabbit hair growth and to test the physical quality of hair tonic. The design of this study was experimental using test animals of New Zealand male rabbits with various concentrations of celery and honey doses for Formula A (5\%: I5\%), Formula B (10\%: 10\%), Formula C (15\%: $15 \%$ ), normal control (without treatment), negative control (additional ingredients), and positive control (hair tonic preparations containing $2 \%$ minoxidil). Physical properties test include organoleptic and $\mathrm{pH}$ test. Measurement of hair growth was observed for I4 days. The results of measurement of hair length and weight were tested statistically by the Anova test method. The results showed that the hair tonic preparation of a combination of celery leaf extract and honey met the $\mathrm{pH}$ requirements and produced stable color, odor, and clarity during storage. The combination of celery leaf extract and honey which has the highest potential for rabbit hair growth is formula $\mathrm{B}$, with a ratio of $10 \%$ extract concentration and $10 \%$ honey and there is no significant difference $(p<0.05)$ with the positive group. The conclusion of this study is that the hair tonic combination of celery leaf extract and honey meets the criteria for 
Physical Quality and Formula B has the highest potential and is as large as a positive control on rabbit hair growth activity This is an open access article under the CC-BY-SA license.

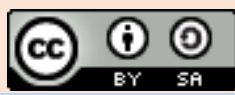

\section{Pendahuluan}

Rambut mempunyai peranan yang sangat penting bagi manusia. Rambut berperan sebagai proteksi terhadap lingkungan yang merugikan, antara lain suhu dingin atau panas dan sinar ultraviolet. Selain itu, rambut juga berfungsi sebagai pengatur suhu, pendorong penguapan keringat dan sebagai indera peraba yang sensitif (Yasir, 2019).

Perawatan rambut tidak cukup hanya dengan menggunakan shampoo yang hanya bersifat sebagai pembersih, namun juga perlu dipelihara dan dirawat sehingga lebih sehat dan indah. Salah satu caranya adalah dengan menggunakan hair tonic. Hair tonic adalah sediaan yang mengandung bahan-bahan yang diperlukan oleh rambut, akar rambut dan kulit kepala (Tranggono \& Latifah, 2007). Saat ini, sediaan hair tonic sudah terdapat banyak dipasaran, baik dari bahan kimia maupun dari bahan herbal. Penggunaan bahan-bahan kimia pada produk kosmetika dinilai kurang aman karena dapat menimbulkan efek samping pada penggunaan jangka panjang.

Penggunaan bahan herbal telah diterima secara luas dinegara berkembang dan di negara maju, tidak hanya pada bidang pengobatan saja, namun juga pada bidang kosmetik. Hal tersebut didukung oleh kekayaan alam Indonesia yang melimpah, terutama dari segi keanekaragaman floranya. Sejak dahulu, nenek moyang kita sudah mengenal cara perawatan rambut menggunakan tumbuhan.

Apigum graveolens L. atau lebih dikenal dengan Seledri merupakan tanaman yang telah banyak digunakan terutama sebagai bahan lalapan dan penyedap masakan. Secara turun temurun, daun seledri telah banyak digunakan sebagai obat reumatik, mata kering, hipertensi, bronchitis, batuk, menurunkan kadar kolesterol serta menyuburkan rambut (Dalimartha, 2000). Pada penelitian sebelumnya telah diketahui ekstrak daun seledri memiliki efek menyuburkan rambut yang optimal pada konsentrasi 10\% dalam krim (Aprilita Rina \& Juriana, 2013). Ekstrak daun seledri dengan konsetrasi 10\% dalam sediaan mikroemulsi ternyata juga mempunyai kemampuan menstimulasi pertumbuhan rambut (Tambunan Lidia, 2012).

Selain seledri, madu telah banyak diketahui sebagai bahan alami yang berguna untuk merawat serta menyehatan kulit kepala dan rambut, karena memiliki banyak kandungan nutrisi. Madu mengandung pinocembrin. Pinocembrin merupakan antioksidan yang penting bagi kesehatan rambut, karena antioksidan mampu meremajakan dan memperbaiki sel-sel rambut yang rusak, menghasilkan jaringan kulit yang kondusif untuk pertumbuhan rambut, dan memperlancar sirkulasi darah yang diperlukan untuk rambut, sehingga rambut menjadi kuat dan tidak kusam (Diana, W, 2014).

Mengacu pada penelitian sebelumnya, maka kedua bahan tersebut apabila dikombinasi akan menghasilkan sediaan yang memiliki khasiat yang lebih optimal. Formula kombinasi ekstrak daun seledri dan madu dalam bentuk sediaan sebagai penumbuh rambut masih sangat terbatas, terutama bentuk sediaan hair tonic. Sediaan hair tonic mudah digunakan, tidak menimbulkan rasa lengket dan tidak membentuk lapisan tipis yang dapat menimbulkan ketombe.

Atas dasar pertimbangan diatas maka dianggap sangat penting untuk dilakukan formulasi dan evaluasi sediaan hair tonic kombinasi ekstrak daun seledri dan madu setra uji aktivitas terhadap pertumbuhan rambut kelinci jantan.

\section{Metode}

\section{Alat dan Bahan}

Alat - alat yang digunakan dalam penelitian ini adalah pisau, nampan, timbangan digital, cawan porselin, batang pengaduk, mortir, stamper, sudip, beker gelas, gelas ukur, water bath, gelas ukur, bakker glass, jangka sorong, blender, kertas saring, $\mathrm{pH}$ meter, pipet tetes, botol.

Bahan yang digunakan dalam penelitian ini adalah etanol, propilen glikol, metil paraben, aquadest, mentol, minoxidil, ekstrak seledri dan madu

Hewan uji yang digunakan pada kelompok ini adalah kelinci jantan jenis New Zealand dengan umur 3-4 bulan dengan berat badan rata-rata $2 \mathrm{~kg}$.

\section{Jalannya Penelitian}

\section{I. Pembuatan Ekstrak Daun Seledri}

Sebanyak I kg daun seledri segar dicuci bersih kemudian dioven. Simplisian kering ditimbang dan dihaluskan dengan belender lalu diayak menggunakan ayakan 50 mesh. Simplisia halus direndam dalam etanol $96 \%$ dengan perbandingan I:I0 b/v selama 24 jam. Hasil rendamen kemudian disaring dan dilakukan proses 
remaserasi menggunakan etanol 96\% sesuai dengan maserasi sebelumnya. Kemudian semua meserat yang talah disaring dikumpulkan dan diuapkan hingga diperoleh ekstrak kental. Ekstrak kental yang di dapat dihitung rendamennya (Kusnadi \& Devi, 2017).

\subsection{Formulasi Sediaan Hair Tonic}

Pada Formula sediaan hair tonic digunakan konsentrasi berdasarkan pada penelitian sebelumnya oleh Juriana dan Yanti (2009) pada sediaan krim dan penelitian oleh Tambunan (2012) pada sediaan mikroemulsi.

\subsection{Pembuatan Hair Tonic}

Ditimbang bahan-bahan yang diperlukan. Dilarutkan metil paraben dengan etanol $96 \%$ di dalam beaker glass, diaduk hingga larut (A). Dimasukkan menthol ke dalam campuran (A), diaduk hingga homogen. Lalu ditambahkan propilen glikol sedikit demi sedikit, diaduk hingga homogen (B). Dicampurkan ekstrak daun seledri ke dalam larutan (B). Dicampurkan madu ke dalam larutan (B). Diaduk hingga homogen Larutan (A) dicampurkan ke dalam larutan (B) sedikit demi sedikit hingga homogeny.

\subsection{Uji Sifat Fisik}

Evaluasi fisik sediaan Hair Tonic yang dilakukan meliputi pengamatan organoleptis dan pengukuran $\mathrm{pH}$

a. Pengamatan Organoleptis

Pengamatan organoleptis sediaan diamati bau, warna dan kemungkinan timbulnya endapan selama penyimpanan(Indriyani \& Endrawati, 202I).

b. Pengukuran $\mathrm{pH}$

Uji $\mathrm{pH}$ dilakukan dengan menggunakan $\mathrm{pH}$ meter. Pengukuran dengan $\mathrm{pH}$ meter dimulai dengan kalibrasi alat. Kalibrasi menggunakan dapar standar $\mathrm{pH} 4$ dan 7. Kemudian elektroda dicelupkan dalam sediaan dan dicatat nilai $\mathrm{pH}$ yang muncul di layar. Pengukuran dilakukan pada suhu ruangan. $\mathrm{pH}$ sediaan hair tonic sebaiknya berkisar antara 3,9-9,5 sesuai dengan $\mathrm{pH}$ untuk sediaan yang digunakan pada kulit kepala(Indriyani \& Endrawati, 202I).

\subsection{Uji Aktivitas pertumbuhan rambut}

Sebanyak 3 ekor Kelinci dicukur bulunya dengan menggunakan alat cukur punggung kelinci yang telah dihilangkan bulunya dibagi menjadi 4 daerah pengujian dengan luas masing-masing $3 \times 3$ $\mathrm{cm}^{2}$ untuk tiap daerah uji menggunakan spidol. Jarak antara daerah uji sekitar I cm. kemudian sebanyak I $\mathrm{ml}$ sediaan uji dioleskan setiap pagi dan malam hari selama 2 minggu berturut-turut. Pengamatan pertumbuhan rambut pada tiap daerah uji dilakukan setelah I4 hari. Kelinci terlebih dahulu dibius menggunakan etil klorida sebelum rambut dicukur. Setelah kelinci kehilangan kesadaran, pencukuran dilakukan dengan hati-hati agar tidak melukai kulit kelinci. Rambut yang dicabut kemudian diukur dengan mistar sedangkan rambut hasil pencukuran ditimbang beratnya menggunakan timbangan digital (Hendriani et al., 2019).

\section{Hasil dan Pembahasan}

Ekstraksi dilakukan dengan metode maserasi, sebanyak $100 \mathrm{~g}$ serbuk daun seledri dimaserasi dengan etanol 96\% menghasilkan 42,7I g ekstrak dengan rendemen 42,71 \%. Maserasi dipilih karena dapat mengekstrak senyawa dengan baik dan dapat mencegah dekomposisi senyawa yang labil terhadap pemanasan.

Ekstrak kental daun seledri yang diperoleh berwarna hijau kecoklatan dan agak berminyak. Ekstrak kental kemudian diformulasikan menjadi sediaan hair tonic. Formula yg digunakan seperti pada tabel I. Sediaan hairtonik yang dihasikan selanjutnya dilakukan uji mutu fisik nya yaitu organoleptik dan uji $\mathrm{PH}$.

Uji organoleptis digunakan untuk memeriksa tampilan fisik dari sediaan Hair tonic menggunakan panca indra. Pengujian organoleptik yang dilakukan adalah pengamatan bentuk, warna, bau yang dilakukan secara visual. Pengamatan dilakuka pada hari ke 7 atau minggu pertama dan hari ke 14 atau minggu ke dua, pada minggu pertama warna dari semua perlakuan terlihat berbeda, untuk Formula A coklat kekuningan, formula B dan C coklat pekat, sementara kontrol negatif bening, Untuk bau dan kejernihan semua perlakuan beraroma khas seledri dan terlihat jernih. Pada minggu ke dua pengamatan dihasilkan warna, bau dan kejernihan yang sama dengan minggu pertama, kondisi ini membuktikan bahwa dari kajian organoleptis sediaan hair tonic tersebut stabil dalam proses penyimpanan.

Tabel I. Formula Sediaan Hair Tonic

\begin{tabular}{llllll}
\hline \multirow{2}{*}{ Bahan } & \multicolumn{3}{l}{ Konsentrasi } & & \\
\cline { 2 - 6 } & $\mathrm{K}(-)$ & FA & FB & FC & $\mathrm{K}(+$ \\
\hline $\begin{array}{l}\text { Ekstrak daun } \\
\text { seledri (\%) } \\
\text { b/v }\end{array}$ & - & 5 & I0 & I5 & - \\
\hline $\begin{array}{l}\text { Madu (\%) } \\
\text { b/v }\end{array}$ & - & I0 & I0 & 5 & - \\
\hline $\begin{array}{l}\text { Alkohol } 96 \% \\
\text { (\%) v/v }\end{array}$ & I7 & I7 & I7 & I7 & - \\
\hline
\end{tabular}




\begin{tabular}{|c|c|c|c|c|c|}
\hline $\begin{array}{l}\text { Propilen } \\
\text { glikol (\%) } \\
\text { b/v }\end{array}$ & 15 & I5 & I5 & I5 & - \\
\hline $\begin{array}{l}\text { Methyl } \\
\text { paraben (\%) } \\
\text { b/v }\end{array}$ & $0, \mathrm{I}$ & $0, I$ & $0, I$ & $0, \mathrm{I}$ & - \\
\hline $\begin{array}{l}\text { Mentol (\%) } \\
\mathrm{b} / \mathrm{v}\end{array}$ & I & $\mathrm{I}$ & $\mathrm{I}$ & $\mathrm{I}$ & - \\
\hline 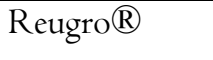 & - & - & - & - & 2 \\
\hline Aquadest & $\begin{array}{l}\text { Add } \\
\text { IOO } \\
\text { ml }\end{array}$ & $\begin{array}{l}\text { Ad } \\
\text { d } \\
\text { I0 } \\
0 \\
\mathrm{ml}\end{array}$ & $\begin{array}{l}\text { Add } \\
\text { IOO } \\
\text { ml }\end{array}$ & $\begin{array}{l}\text { Add } \\
\text { IOO } \\
\mathrm{ml}\end{array}$ & - \\
\hline
\end{tabular}

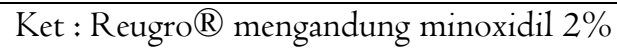

PH merupakan parameter yang dapat mempengaruhi daya absorpsi sediaan kedalam kulit. Pemeriksaan $\mathrm{pH}$ bertujuan untuk melihat derajat keasaman dari sediaan hairtonic. Uji pH merupakan salah satu dari uji secara kimia dalam menentukan kestabilan sediaan hairtonic selama penyimpanan, nilai $\mathrm{PH}$ yang dapat diterima oleh kulit berkisar 4,56,5 (Darajati \& Ambari, 202I). Hasil pengukuran $\mathrm{pH}$ selama 2 minggu berturut-turut dapat dilihat pada tabel 2 .

Tabel 2. Hasil pengukuran $\mathrm{pH}$ sediaan hair tonic selama 2 minggu penyimpanan.

\begin{tabular}{lll}
\hline Sediaan Hair Tonic & $\mathrm{pH}$ & \\
\cline { 2 - 3 } & Minggu I & Minggu 2 \\
Kontrol Negatif & 6,7 & 6,5 \\
Formula I & 4,7 & 4,6 \\
Formula 2 & 4,7 & 4,6 \\
Formula 3 & 4,7 & 4,6 \\
\hline
\end{tabular}

Penurunan $\mathrm{pH}$ yang terjadi kemungkinan disebabkan adanya hidrolisis dari sediaan yang melepaskan sejumlah ion hidrogen. Penurunan $\mathrm{pH}$ juga dapat disebabkan karena pengaruh masuknya CO2 ke dalam wadah pada saat pengukuran dilakukan. Hasil pengamatan menunjukkan rentang PH yang aman yaitu 4-6 pada I4 hari masa penyimpanan (Darajati \& Ambari, 202I).

Uji Aktivitas Pertumbuhan Rambut

Pengujian aktivitas pertumbuhan hair tonic rambut ekstrak daun seledri dan madu dilakukan terhadap kelinci dengan jenis, berat dan umur yang seragam. Pada penelitian ini, metode yang digunakan untuk mengevaluasi keefektifan hair tonic adalah modifikasi metode (Mulyanti et al., 2019). Pengujian dilakukan selama 2 minggu dengan pemberian sediaan uji setiap hari berturut-turut pada pagi dan malam hari. Sediaan uji yang dioleskan pada kelinci terdiri dari enam sediaan berbeda yaitu kontrol normal, kontrol negatif, kontrol positif serta formulasi A, formula B dan formula C. Khusus sediaan hair tonic formula A, B dan C dilakukan pengulangan sebanyak 3 kali sehingga untuk setiap formulasi dilakukan pengolesan pada 3 daerah uji yang berbeda pada kelinci. Pengulangan ini dilakukan untuk meningkatkan kepastian hasil yang akan diperoleh dari pengujian.

Pengamatan hasil dilakukan setelah 2 minggu pengujian. Pengamatan hanya dilakukan setelah 2 minggu pengujian karena pertumbuhan rambut normal berkisar I/3 milimeter perhari atau sekitar I cm perbulan, sehingga sekitar 2 minggu panjang rambut yang tumbuh sudah dapat diamati dan diukur(Mulyanti et al., 2019). Selain itu, dari sisi kode etik hewan, dikhawatirkan akan menimbulkan rasa sakit dan resiko yang besar bila pengamatan dilakukan setiap minggu. Proses pencabutan rambut dan pencukuran rambut diawali dengan pembiusan beresiko hewan mati sehingga pengamatan dilakukan hanya pada akhir waktu pengujian.

Pengamatan dilakukan dengan mengukur panjang rambut kelinci dan menimbang berat rambut kelinci yang tumbuh pada setiap daerah uji. Pengukuran panjang rambut dapat digunakan untuk menyatakan kemampuan hair tonic ekstrak daun seledri dalam menstimulasi panjang rambut kelinci. Pengukuran panjang rambut dilakukan dengan mencabut 3 helai rambut pada masing-masing daerah uji kemudian panjang rambut diukur menggunakan mistar. Hasil pengukuran panjang rambut kelinci untuk semua perlakuan disajikan pada gambar I.

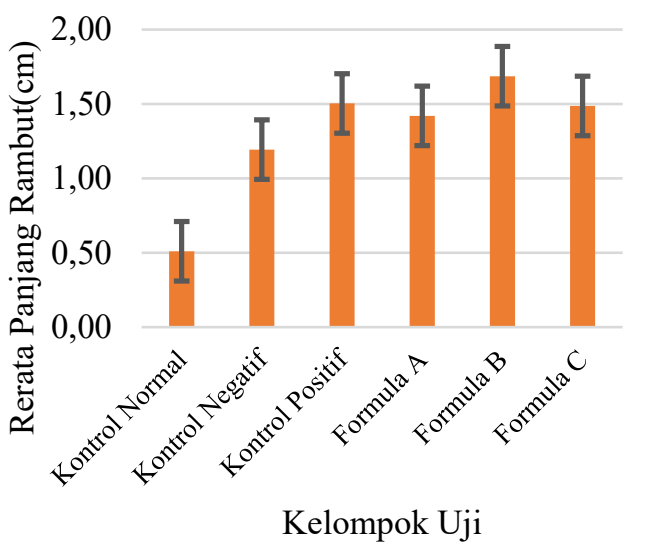

Gambar I. Rerata Panjang Rambut ( $\mathrm{cm}$ )

Penimbangan berat rambut dapat dijadikan parameter untuk mengetahui pengaruh hair tonic ekstrak daun seledri terhadap kelebatan rambut pada kelinci. Hasil pengukuran berat rambut kelinci untuk semua perlakuan disajikan pada gambar 2 . 


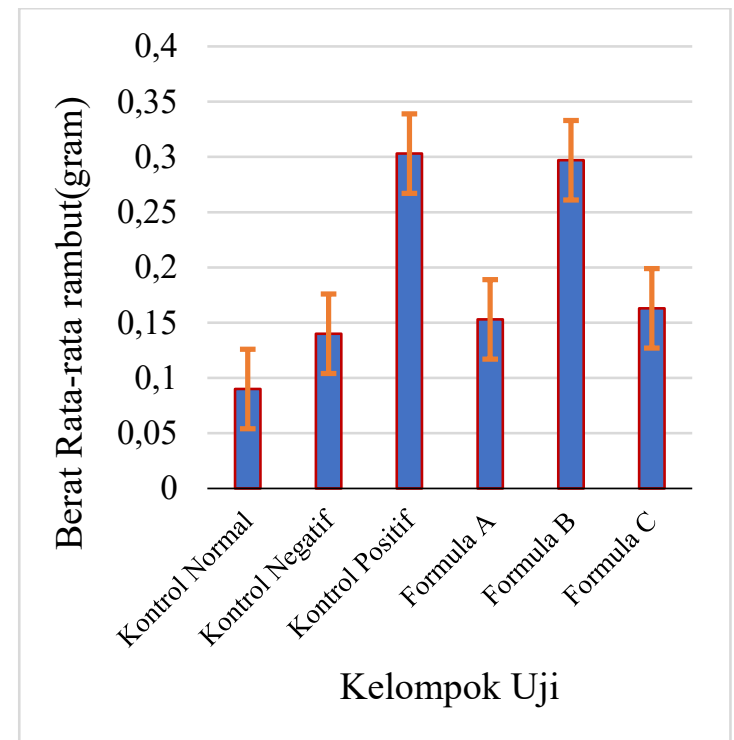

Gambar 2. Rerata Berat Rambut (gram)

Hasil pengamatan tersebut menunjukkan bahwa konsentrasi ekstrak daun seledri dan madu pada sediaan hair tonic yang paling baik menstimulasi pertumbuhan rambut adalah formula B dengan konsentrasi (10\%: 10\%). Panjang rambut kelinci kontrol normal tidak diberikan perlakuan dan stimulansi sehingga bila dibandingkan dengan kelompok uji lain akan menunjukkan panjang rambut yang cukup berbeda.

Untuk mengetahu perbedaan antar kelompok perlakuan dilakukan Perhitungan statistik panjang dan berat rambut kelinci pada minggu kedua ,hasil menunjukkan data terdistribusi normal dan homogen. Hasil uji ANOVA menunjukkan bahwa kelompok normal dengan kelompok negatif, formula $\mathrm{A}$, dan $\mathrm{C}$ mempunyai perbedaan yang signifikan. Dalam uji Duncan formula yang terbaik yaitu formula B dan kontrol positif (Regrou ${ }^{\circledR}$ ) karna tidak ada perbedaan yang signifikansi, tetapi rata-rata uji statistik anova formula B lebih tinggi dibandingkan kontrol normal, seperti terlihat pada tabel 3.

Tabel 3. Uji statistik Panjang dan Berat Rambut Kelinci

\begin{tabular}{lcc}
\hline Kelompok & $\begin{array}{c}\text { Panjang rambut } \\
(\text { mean } \pm \text { SD }) \\
(\mathrm{Cm})\end{array}$ & $\begin{array}{c}\text { Berat rambut } \\
(\text { mean } \pm \text { SD }) \\
(\mathrm{Gram})\end{array}$ \\
\hline Normal & $0.7267 \pm .00577$ & $0.0900 \pm .01000$ \\
Negatif & $1.1967 \pm .02517$ & $0.1400 \pm .01000$ \\
Positif & $1.7200 \pm .01000^{*}$ & $0.3033 \pm .00577^{*}$ \\
Formula A & $1.4800 \pm .01732$ & $0.1533 \pm .02517$ \\
Formula B & $1.7300 \pm .02646^{*}$ & $0.3200 \pm .01732^{*}$ \\
Formula C & $1.5967 \pm .03786$ & $0.1633 \pm .01528$ \\
\hline
\end{tabular}

Ket : Tanda (*) menunjukan tidak ada perbedaan yang signifikan $(\mathrm{p}<0,05)$

Dari data statistik pada tabel 3 menunjukkan panjang rambut dan berat rambut kelinci pada minggu kedua setelah perlakuan menunjukkan kelompok normal dengan semua kelompok perlakuan terlihat berbeda bermakna satu sama lain, artinya kontrol normal dengan semua perlakuan memiliki kemampuan yang berbeda dalam menstimulai pertumbuhan rambut kelinci. Sedangkan hal berbeda terjadi pada Kontrol Positif dengan Formula B menunjukkan tidak ada perbedaan yang bermakna diantara keduanya, hal ini dapat di artikan kontrol positif dan Formula B memiliki potensi yang sama dalam menstimulasi pertumbuhan rambut dilihat dari pengukuran panjang rambut dan berat rambut kelinci setelah dua minggu perlakuan.

Pertumbuhan rambut normal ini sangat dipengaruhi oleh lama dan kecepatan tumbuh rambut selama fase anagen dan katagen. Kandungan apiin dan apigenin yang besar dalam daun seledri mengakibatkan vasodilatasi pembuluh darah. Apiin merupakan glikosida flavonoid yang mengalami hidrolisis sehingga menjadi aglikon apigenin. Pelebaran pembuluh darah di rambut memungkinkan tercukupinya suplai darah yang lancar untuk proses pertumbuhan rambut(Kusnadi \& Devi, 2017).

\section{Simpulan}

Berdasarkan hasil penelitian tentang uji aktivitas pertumbuhan rambut pada kelinci dari sediaan hair tonic ekstrak daun seledri dan madu, maka dapat dibuat kesimpulan sebagai berikut : I). Sediaan hair tonic yang mengandung ekstrak daun seledri dan madu dengan dosis 5\%: 10\%, I0\% : 10\%, I5\% : $5 \%$ memenuhi persyaratan mutu fisik ditinjau dari segi warna, bau dan kehomogenitas yang stabil selama penyimpanan dan $\mathrm{pH}$ sediaan hair tonic memenuhi persyaratan $\mathrm{pH}$ kulit kepala; 2).Kombinasi ekstrak daun seledri dan madu yang memiliki potensi paling tinggi terhadap pertumbuhan rambut kelinci adalah formula $\mathrm{B}$, dengan perbandingan konsentrasi ekstrak $10 \%$ dan madu $10 \%$ dan tidak ada perbedaan yang signifikan $(p<0,05)$ dengan kelompok positif (sediaan hair tonic mengandung minoxidil Reugro $(2 \%)$.

\section{Daftar Pustaka}

Aprilita Rina, Y., \& Juriana. (20I3). PENGARUH PEMBERIAN KRIM EKSTRAK AIR DAUN SELEDRI (Apium graveolens Linn.) SEBAGAI STIMULAN 
PERTUMBUHAN RAMBUT TIKUS

PUTIH (Rattus norvegicus L.) JANTAN

GALUR SPRAGUE DAWLEY (SD).

Bahan Alam Indonesia, 7(4).

Dalimartha, S. (2000). Atlas Tumbuhan Obat Indonesia (Ist ed.).

Darajati, W. P., \& Ambari, Y. (202I). Formulasi dan Uji Stabilitas Fisik Sediaan Hair Tonic Ekstrak Daun Cabai Rawit (Capsium Frutescent L). Dengan Variasi Propilenglikol Dan Etanol 96\%. Journal of Pharmaceutical Care Anwar Medika, 3(2), I5I-I60. https://doi.org/I0.36932/jpcam.v3i2.70

Diana, W, W. M. (20I4). Penggunaan Ekstrak Buah Alpukat dan Madu Sebagai Bahan Aktif Hair Tonic Untuk Rambut Rontok. EJournal, O3(0I), 226-235.

Hendriani, I. N., Tamat, S. R., \& Wibowo, A. E. (2019). Uji Aktivitas Sediaan Hair Tonic Kombinasi Daun Pare (Momordica charantia) dan Ekstrak Wortel (Daucus carota L.) Pada Kelinci Jantan New Zealand White. Jurnal Ilmiah Kedokteran: Fakultas Farmasi Universitas Pancasila, 6(2), I43I47.

Indriyani, F., \& Endrawati, S. (202I). Formulasi dan Uji Stabilitas Hair Tonic Ekstrak Lidah Buaya (Aloe vera L.) dan Seledri (Apium graviolens L.). Indonesian Journal on Medical Science, 8(I), I6-24.

Kusnadi, \& Devi, triana E. (2017). Pancasakti Science Education Journal. 2(9), 56-67.

Mulyanti, G. D., Nurhayati, Y., \& Ariska, A. (2019). Uji Efek Formulasi Sediaan Hair Tonic Perasan Daun Kacang Panjang (Vigna sinensis (1.) savi ex hassk) Terhadap Pertumbuhan Rambut Kelinci Kantan. Wellness and Healthy Magazine, 2(Agustus), 285-294.

Tambunan Lidia, R. (2012). Uji Stabilitas Mikroemulsi Ekstrak Daun Seledri dan Mikroemulsi Ekstrak Daun Urang Aring dan Efektivitasnya Terhadap Pertumbuhan Rambut Tikus Jantan Spraque Dawley [UI]. https://doi.org/Jakarta: Universitas Indonesia

Tranggono, I., \& Latifah, F. (2007). Buku Pengangan Ilmu Pengetahuan Kosmetik. Gramedia Pustaka Utama.

Yasir, A. S. (2019). Sediaan Hair Tonic Yang Mengandung Ekstrak Etanol. 2(I), 76-85. 